\title{
Profesyonel, Amatör ve Sedanter Futbol Oynayanların Fiziksel, Fizyolojik ve Motorik Özelliklerinin Değerlendirilmesi - Anaerobik Dayanıklılıklarını Etkileyen Faktörlerin Belirlenmesi
}

\author{
Determination of Physical, Physiological and Motoric Characteristics
}

of Professional, Amateur and Sedentary Footballers - Determination of

\author{
Factors Affecting Anaerobic Endurance
}

\section{ORİJINAL ARAŞTIRMA/ \\ ORIGINAL RESEARCH}

Emre SERIN ${ }^{1}$,

${ }^{1}$ Mersin Üniversitesi, Spor Bilimleri Fakültesi, Mersin

https://orcid.org/0000-0001-9596-2912
$\ddot{\mathbf{O z}}$

$\mathrm{Bu}$ çalışmanın amacı profesyonel, amatör ve sedanter olarak futbol oyuncularının fiziksel, fizyolojik ve motorik özelliklerinin tespiti aynı zamanda anaerobik dayanıklılıklarını etkileyen faktörlerin belirlenmesidir. Çalışmaya yaşları ortalaması $22,65 \pm 3,68$ yıl; boy uzunluğu 1,76, $\pm 10 \mathrm{~cm}$; vücut ağırlığ $71,94 \pm 8,53 \mathrm{~kg}$; beden kütle indeksi (BKI) 22,96 $\pm 2,46 \mathrm{~kg} / \mathrm{m} 2$ olmak üzere farklı kategorilerde futbol oynayan toplam 60 kişi gönüllü olarak katılmıştır. Bulgular incelendiğinde istirahat kalp atımları sıra farklarına göre düşük değerden büyük değere doğru gruplar sıralandığında farkın anlamlı olduğu görülmüştür (X $2=36,935, p<0,05$ ). Hesaplanan sıra ortalama değerlerine bakıldığında; katılımcıların istirahat kalp atımı değişkeni bakımından, profesyoneller $(815,41)$, sedanterler $(50,21)$ ve amatörler $(29,89)$ biçiminde sıralanmaktadır. Kruskal Wallis H testi sonuçlarına göre 1sınma sonrası kalp atım değişkenine göre yine grupların sıra farkları incelendiğinde amatör ve sedanter gruplar arasındaki sıra farkı anlamlı bulunmuştur $(p<0,05)$. Sonuç olarak, maksimum efor gerektiren çalışmalara adaptasyon sağlamak amaciyla ısınma çalışmalarına yer vermek aynı zamanda uzun yıllar spor yapmak anaerobik dayanıklılık performansını olumlu yönde farklılaşmasına yol açmaktadır. Oyunun ve 1sınmanın karakterine, sporcu yaşı ve antrenman seviyesine paralel olarak fiziksel, fizyolojik ve motorik bileşenlerin farklılaştığı düşünülmektedir.

Anahtar Kelimeler: Fiziksel, Fizyolojik, Anaerobik Dayanıklılık, Kalp atımı.

\begin{abstract}
The aim of this study; physical, physiological and motoric properties of football players as professional, amateur and sedentary. The mean age of the study was 22.65 \pm 3.68 years; length $1,76 \pm 10 \mathrm{~cm}$; body weight $71.94 \pm 8.53 \mathrm{~kg}$; body mass index (BMI) $22.96 \pm 2.46 \mathrm{~kg} / \mathrm{m} 2$ in total 60 people playing football in different categories participated voluntarily. When the findings were examined, it was found that the difference was significant when the groups were ranked from low to large according to the sequence differences of resting heart beats $(X 2=36,935, p<0.05)$. When the calculated average values are; In terms of the participants' resting heart rate variable, professionals $(815,41)$, sedentaries $(50,21)$ and amateurs $(29,89)$ are listed as. According to the results of Kruskal Wallis H test, the difference between the amateur and sedentary groups was found to be significant $(p<0.05)$. When anaerobic endurance variables were examined, the order differences between the groups were found to be significant ( $\mathrm{p}<0.05$ ). It can be thought that physical, physiological and motoric components differ in parallel with the character of play and warming, athlete age and training level.
\end{abstract}

Keywords: Physical, Physiological, Anaerobic Endurance, Heartbeat.
Yayın Bilgisi

Gönderi Tarihi: 25.10.2019

Online Yayın Tarihi: 31.12.2019

DOI: $10.33459 /$ cbubesbd.638119 


\section{GİRIŞ̧}

Performansı etkileyen birçok etmen vardır. Bunlardan bir tanesi de fiziksel yapıdır. Bir başka deyişıle fiziksel özelliklerdir. Çünkü bireyin fiziksel yapısı birçok fizyolojik bileşenini de etkilemektedir. Bireyin sahip olduğu fiziksel yapı yapmış olduğu branşın gereksinimlerine uygun olmadıkça üstü düzey performans göstermesi pekte mümkün olmayacaktır. Sporcuların fiziksel özellikleri performans göstergelerinden sadece birisidir. Bununla beraber diğer motorik özelliklerinin de yerinde olması performansı olumlu yönde etkilemektedir (Açıkada ve Ergen, 1990).

Futbolda performans birçok değişene bağlıdır. Bunların bir kısmı; "teknik, taktik, fiziksel, fizyolojik ve psikolojik unsurlar" Bunların yanı sıra futbol oyununun yapısı, oyuncunun taktik ve teknik becerisi, çevre koşulları, oynadığı seviye ve lig, oyun tarzı gibi daha birçok koşula bağlıdır (Re1lly, 1996).

Futbol, 'Aerobik ve anaerobik eforların ardı ardına kullanıldığı sürat, kuvvet, çeviklik, esneklik, hareketlilik, denge, kassal ve kardio-respiratuvar dayanıklılık, koordinasyon gibi faktörlerin performansa beraberce etki ettiği yüksek derecede koordine bir spor disiplini'” olarak tanımlanmıştır (Akgün, 1994).

Futbol müsabakası esnasında elit düzeydeki oyuncuların kalp atımları maksimum seviyelere ulaşmaktadır. Ortalama 10km anaerobik eşiğe yakın bir yoğunlukta koşarlar. Bu dayanıklılık istemektedir ve bu dayanıklılığın içinde oyuncular 'sıçrama, topa vurma, sprint' gibi değişenleri sürekli gerçekleştirmektedir. Dolayısıyla futbol oyucuları bir alanda üst düzey performansa ulaşmak yerine futbolda başarılı performansın gerektirdiği tüm değişenlerde yeterli kapasitede olmak zorundadırlar (Stolen, Chamarı, Castagna ve Wisloff,2005).

Profesyonel kavramı, "kendi veya bir başka şahıs için seyirci kabul ederek, paralı seyirci önünde, sportif müsabaka ve yarışmaya katılma karşılığında toplanan hasılattan pay almak” şeklinde açıklanabilir (Şahin, 2006). Bu durum göz önünde bulundurulduğunda sporcu kendini gösterebilmek ve yahut ispatlayabilmek adına gerekenden daha fazla performans göstermek durumunda kalır. Dolayısıyla bu farkındalığı yaratabilmesi için morfolojik ve fonksiyonel açıdan normalüstünde olması gerekmektedir. Böylece normalde yapmadığı kadar fiziksel çalışma içerisinde bulunmaktadır (Aslan, İnan ve Akalan, 2010). Popülerliği son yıllarda artan, sağlık ve 
Serin, E. (2019). Profesyonel, amatör ve sedanter futbol oynayanların fiziksel, fizyolojik ve motorik özelliklerinin değerlendirilmesi. Anaerobik dayanıklılıklarını etkileyen faktörlerin belirlenmesi CBÜ Beden Eğitimi ve Spor Bilimleri Dergisi, 14 (2), 344-355.

rekreatif amaçla spor yapmak profesyonel amaçla spor yapma kadar rağbet görmektedir. Bireyler bu şekilde yoğun ve tüketen egzersizler yerine şiddeti düşük egzersizler yapmaktadır. Bu şekilde sınırlarını zorlamak yerine mevcut fiziksel, fizyolojik ve motorik özelliklerini korumayı amaçlamaktadırlar (Aslan, İnan ve Akalan, 2010).

Gün geçtikçe sağlığı koruma amacıyla ve rekreasyonel amaçla yapılan sporlar profesyonel amaçla yapılan sporlar kadar popüler hale gelmektedir. Bu bağlamda kişiler şiddeti ve kapsamı yoğun antrenmanlar yerine nispeten şiddeti düşük daha az yorucu metotlar tercih etmektedirler. Böylelikle kişiler daha büyük performanslar ortaya koymak yerine mevcut olan fiziksel fizyolojik bileşenleri korumaya yönelik girişimlerin içinde bulunmaktadırlar. Performansla böyle bir ilişki literatüre "Herkes İçin Spor”, "Sağlık İçin Spor” gibi kavramlar ile girmiş ve "Sağlık ve sağlık amacını beraber gerçekleştirmeyi amaç edinen” (Özer, 2001). “amatör aktiviteler” olarak tanımlanmıştır (Arslan, İnan, Akalan, 2010).

Tüm spor branşların da olduğu gibi futbolda da performansı olumlu yönde etkilenen özellikler vardır. Bunlar; dayanıklılık, kuvvet, sürat ve beden kompozisyonsundur. Futbolcuların vücut kitle indeksleri ile dayanıklılık ve kuvvet özelliklerinin aralarında yüksek ilişkiler ve farklılıklar bulunması, sporcuların performanslarının kısmen de olsa vücut yağ oranlarına bağlık olması, futbolcuların fiziksel özelliklerinin ve performans sınırlılıklarının araştırılması gereksinimini ortaya çıkartmaktadır(Günay, Erol ve Savaş, 1994). Özellikle topu kazanma mücadelesinde kalça, bacak ve diğer alt vücut kasları kullanılır (Karatosun, 1991; Serin, 2017).

Futbolcuların fiziksel, fizyolojik ve motorik özellikleri üzerine yapılmış birçok çalışma olmasına rağmen, profesyonel, amatör ve sedanter olarak futbol oynayanların bu bileşenlerinin tespiti aralarında farkın değerlendirmesi, aynı zamanda anaerobik dayanıklılık performanslarını etkileyen faktörlerin tespiti ile ilgili çalışmaların yok denecek kadar sınırlı olduğu söylenebilir. Bu bağlamda; bu çalışmanın amacı, profesyonel, amatör ve sedanter futbolcularda fiziksel, fizyolojik ve motorik özelliklerin tespiti değerlendirmesi anaerobik dayanıklılık performanslarına etki eden faktörlerin incelenmesidir. 
Serin, E. (2019). Profesyonel, amatör ve sedanter futbol oynayanların fiziksel, fizyolojik ve motorik özelliklerinin değerlendirilmesi. Anaerobik dayanıklılıklarını etkileyen faktörlerin belirlenmesi CBÜ Beden Eğitimi ve Spor Bilimleri Dergisi, $14(2), 344-355$.

\section{YÖNTEM}

\section{Çalışma Grubu}

Araştırmaya Güney Anadolu bölgesi bal ligi, amatör ligi ve setanter olarak spora katılım gösteren sadece halı sahalarda futbol oynayan toplam da 60 kişi katılmıştır. Araştırmaya katılanların \% 36,7'si (n=22) profesyonel ve \% 31,7'si $(\mathrm{n}=19)$ amatör düzeyde futbol oyuncusu iken \% 31,7'si de (n=19) sedanter grupta bulunmaktadır. Gruplara göre araştırmaya katılanların ayrıntılı demografik bilgileri Tablo 1'de verilmiştir. Bu araştırma Siirt Üniversitesi tesislerinde yapıld1.

\section{Veri Toplama Aracı}

\section{Boy Ölçümü}

Sporcuların boy uzunlukları duvar skalası ile ölçülmüşsür. Sporcular düz bir zemin üzerinde anatomik pozisyonda iken, yalın ayak ve dik pozisyonda, duvar skalasına sırtı dönük şekilde ölçülmüştür. Görünen değerler cm. cinsinden kaydedilmiştir.

\section{Vücut Ağırlığını Ölçümü}

Vücut ağırlığını ölçmek için Fakir Hausgerate / Hercules markalı elektronik tartı kullanılmış. Sporcular çıplak ayak ve hafif spor kıyafetleriyle ölçüme girmişlerdir. Görünen değerler kg. cinsinden kaydedilmiştir.

\section{Kalp Atım Sayısının Ölçümü}

Isınma öncesi, sonrası ve anaerobik dayanıklılık öncesinde ve sonrasında sporcuların KAS'1 kalp atım monitörü (RS 800, Polar Vantage NV, Polar Electro Oy, Finland) ile 5 snlik aralıklarla kaydedilmiştir. Çalışma öncesinde kalp atım monitörünün gögüs bandı sporcunun göğsüne yerleştirilmiş ve monitörden KAS kaydedilmiştir.

\section{Vücut Kitle İndeksi}

Çalışmaya katılan öğrencilere Tanita BC 418 cihazı ile Biyoelektrik İmpedans Analizi yapılarak Vücut Kütle İndeksleri belirlendi ve elde edilen vücut kompozisyonları kaydedildi. 
Serin, E. (2019). Profesyonel, amatör ve sedanter futbol oynayanların fiziksel, fizyolojik ve motorik özelliklerinin değerlendirilmesi. Anaerobik dayanıklılıklarını etkileyen faktörlerin belirlenmesi CBÜ Beden Eğitimi ve Spor Bilimleri Dergisi, $14(2), 344-355$.

\section{Anaerobik Dayanıklılık Testi}

Üç köşe koşu testi, bu test anaerobik dayanıklılığı ölçer. Testte başlamadan önce sporcuların kalp atımları kaydedilir. Sporcu başlangıç noktasında çıkış pozisyonu alır. Sporcu hazır ve çık komutuyla 80 metrelik mesafedeki birinci bayrak direğine koşar ve bayrak direğinin etrafından dönerek 20 metrelik mesafedeki ikinci bayrak direğine koşar ve bayrak direğinin etrafından dönerek başlangıç noktasındaki üçüncü bayrak direğine koşar (82,4 metre) ve bayrak direğinin etrafından dönerek dördüncü bayrak direğine koşarak testi bitirir. Koşu sonrası kalp atımları kaydedilir. Ölçümler saniye cinsinden değerlendirilir (Serin ve Taşkın, 2016; Taşkın, 2009).

\section{Verilerin Analizi}

Verilerin değerlendirilmesinde ve hesaplanmış değerlerin bulunmasında SPSS 16,0 istatistik paket program kullanıldı. Verilerin tanımlayıcı istatistikleri ortalama ve standart sapmalar verilerek özetlendi. Gruplar arasındaki sıra farkının incelenmesi açısından Kruskal Wallis H testi uygulandı. Dayanıklılık üzerinde anlamlı etkileme gücüne sahip parametrelere ilişkin yapılan Çoklu Doğrusal Regresyon analizi uyguland.

\section{BULGULAR}

\section{Demografik Bulgular}

Araştırmada elde edilen verilerin demografik dağılımı Tablo 1'deki gibidir.

Tablo 1.Araştırmaya Katılanların Demografik Bilgileri, Basıklık ve Çarpıklık Değerleri

\begin{tabular}{lcccccrr}
\hline Değişenler & $\mathbf{N}$ & Min & Max & M & SD & Skewness & Kurtosis \\
\hline Yaş (yıl) & 60 & 18,00 & 39,00 & 22,65 & 3,68 & 2,020 & 5,791 \\
\hline Boy (cm) & 60 & 1,18 & 1,91 & 1,76 &, 10 & $-3,116$ & 18,236 \\
\hline Kilo (kg) & 60 & 53,90 & 86,30 & 71,95 & 8,53 &,- 167 &,- 881 \\
\hline VKİ & 60 & 18,70 & 28,40 & 22,96 & 2,46 &, 145 &,- 330 \\
\hline
\end{tabular}


Serin, E. (2019). Profesyonel, amatör ve sedanter futbol oynayanların fiziksel, fizyolojik ve motorik özelliklerinin değerlendirilmesi. Anaerobik dayanıklılıklarını etkileyen faktörlerin belirlenmesi CBÜ Beden Eğitimi ve Spor Bilimleri Dergisi, 14 (2), 344-355.

Tablo 1'deki bulgular incelendiğinde, araştırmaya katılan futbolcu çocukların fiziksel ve

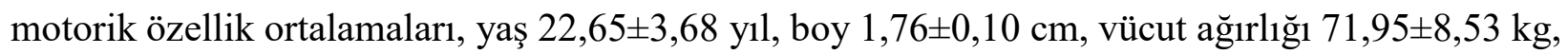
ve vücut kitle indeksleri ortalaması $22,96 \pm 2,46 \mathrm{~kg} / \mathrm{m} 2$ olarak tespit edilmiştir.

Tablo 2.Gruplara İlişkin Sıra Farkları Kruskal Wallis H Testi Sonuçları

\begin{tabular}{|c|c|c|c|c|c|c|c|}
\hline Değişenler & Grup & $\mathrm{N}$ & Sira Fark & $\mathrm{X} 2$ & $\mathrm{df}$ & $\mathrm{p}$ & Anlamlilik \\
\hline \multirow{3}{*}{$\begin{array}{l}\text { VKI } \\
(\mathrm{kg} / \mathrm{m} 2)\end{array}$} & Prof. & 22 & 31,75 & \multirow{3}{*}{0306} & \multirow{3}{*}{2} & ,858 & \\
\hline & Amatör & 19 & 28,76 & & & & \\
\hline & Sedanter & 19 & 30,79 & & & & \\
\hline \multirow{3}{*}{$\begin{array}{l}\text { Sağ ve Sol } \\
\text { Bac.Kas. Mik. } \\
\text { Ort (kg) }\end{array}$} & Prof. & 22 & 30,93 & \multirow{3}{*}{,983 } & \multirow{3}{*}{2} & ,612 & \\
\hline & Amatör & 19 & 27,47 & & & & \\
\hline & Sedanter & 19 & 33,03 & & & & \\
\hline \multirow{3}{*}{$\begin{array}{l}\text { Mineral } \\
\text { Mik. (kg) }\end{array}$} & Prof. & 22 & 33,16 & \multirow{3}{*}{2,122} & \multirow{3}{*}{2} & ,346 & \\
\hline & Amatör & 19 & 25,71 & & & & \\
\hline & Sedanter & 19 & 32,21 & & & & \\
\hline \multirow{3}{*}{$\begin{array}{l}\text { Protein } \\
\text { Mik. (kg) }\end{array}$} & Prof. & 22 & 32,73 & \multirow{3}{*}{,683 } & \multirow{3}{*}{2} & ,711 & \\
\hline & Amatör & 19 & 30,18 & & & & \\
\hline & Sedanter & 19 & 28,24 & & & & \\
\hline \multirow{3}{*}{$\begin{array}{l}\text { Din. Kah. } \\
\text { (atım/dk) }\end{array}$} & Prof. & 22 & 15,41 & \multirow{3}{*}{36,935} & \multirow{3}{*}{2} & ,000 & \multirow{3}{*}{$\begin{array}{c}\text { Prof }<\text { Amat }<\text { Sec } \\
\text { an }\end{array}$} \\
\hline & Amatör & 19 & 29,89 & & & & \\
\hline & Sedanter & 19 & 48,58 & & & & \\
\hline \multirow{3}{*}{$\begin{array}{l}\text { Isınma Kah. } \\
\text { (atım/dk) }\end{array}$} & Prof. & 22 & 22,91 & \multirow{3}{*}{35,871} & \multirow{3}{*}{2} & ,000 & \multirow{3}{*}{ Ama $<$ Sedan } \\
\hline & Amatör & 19 & 19,58 & & & & \\
\hline & Sedanter & 19 & 50,21 & & & & \\
\hline \multirow{3}{*}{$\begin{array}{l}\text { Anaerobik } \\
\text { Dayanıklılık (sn) }\end{array}$} & Prof. & 22 & 15,14 & \multirow{3}{*}{31,812} & \multirow{3}{*}{2} & ,000 & \multirow{3}{*}{$\begin{array}{l}\text { Prof }<\text { Ama } \\
\text { Prof }<\text { Sedan } \\
\text { Ama }<\text { Sedan }\end{array}$} \\
\hline & Amatör & 19 & 33,11 & & & & \\
\hline & Sedanter & 19 & 45,68 & & & & \\
\hline \multirow{3}{*}{ Spor yaşı (yıl) } & Prof. & 22 & 44,18 & \multirow{3}{*}{30,736} & \multirow{3}{*}{2} & 2,000 & Prof>Ama \\
\hline & Amatör & 19 & 31,11 & & & & Prof $>$ Sedan \\
\hline & Sedanter & 19 & 14,05 & & & & Ama $>$ Sedan \\
\hline
\end{tabular}

Tablo 2 'deki diğer bulgular incelendiğinde araştırmaya katılan grupların VKİ, sağ ve sol bacak kas miktarı ortalamaları, mineral miktarı ve protein miktarı değişkenleri bakımından gruplar arasındaki sıra farkları anlamlı bulunmamıştır $(\mathrm{p}>0,05)$. Ancak dinlendik kalp atımı, sıra farklarına göre düşük değerden büyük değere doğru gruplar sıralandığında farkın anlamlı olduğu görülmüştür $(\mathrm{X} 2=36,935, \mathrm{p}<0,05)$. Hesaplanan sıra ortalama değerlerine bakıldığında; katılanların dinlenik kalp atımı değişkeni bakımından profesyonel olanlar $(815,41)$, sedanter olanlar $(50,21)$ ve amatörler $(29,89)$ biçiminde sıralanmaktadır. Kruskal Wallis H testi sonuçlarına göre isınma sonrası kalp atımları değişkenine göre yine grupların sıra farkları incelendiğinde amatör ve sedanter gruplar arasındaki sıra farkı anlamlı bulunmuştur $(X 2=35,935, \mathrm{p}<0,05)$. Grupların sıra 
Serin, E. (2019). Profesyonel, amatör ve sedanter futbol oynayanların fiziksel, fizyolojik ve motorik özelliklerinin değerlendirilmesi. Anaerobik dayanıklılıklarını etkileyen faktörlerin belirlenmesi CBÜ Beden Eğitimi ve Spor Bilimleri Dergisi, 14 (2), 344-355.

ortalama değerleri incelendiğinde amatörler $(19,58)$ ve sedanterler $(50,21)$ biçiminde siralandiğ 1 anlaşılmaktadır. Anaerobik dayanıklılık değişkeni bakımından incelendiğinde gruplar arasındaki sıra farkları anlamalı bulunmuştur $(\mathrm{X} 2=31,812, \mathrm{p}<0,05)$. Grupların sıra ortalama değerleri profesyonel $(15,14)$, amatör $(33,11)$ ve sedanterler $(45,68)$ biçiminde olduğu görülmektedir. Yine analiz sonuçlarına göre spor yapma yaşı bakımından grupların sıra farkları anlamalı bulunmuştur $(\mathrm{X} 2=30,736, \mathrm{p}<0,05)$. Grupların sıra ortalama değerleri incelendiğinde profesyoneller $(44,18)$, amatörler $(31,11)$ ve sedanterler $(14,05)$ olarak sıralandığı anlaşılmaktadır.

Anaerobik dayanıklılık üzerinde anlamlı etkileme gücüne sahip parametrelere ilişkin yapılan Çoklu Doğrusal Regresyon analizinde değişkenlere ilişkin ortalama, standart sapma ve korelasyon katsayıları Tablo 3'te verilmiştir.

Tablo 3.Değişkenlere İlişkin Ortalama, Standart Sapma ve Korelasyon Katsayıları (N=60)

\begin{tabular}{|c|c|c|c|c|c|c|c|}
\hline Değişkenler & M & SD & 1 & 2 & 3 & 4 & 5 \\
\hline 1. Anaerobik Dayanıklılık (sn) & 32,59 & 3,14 & 1 & & & & \\
\hline 2. VKİ (kg/m2 ) & 22,96 & 2,46 &, 062 & 1 & & & \\
\hline 3. Isınma KAH. (atım/dk) & 130,70 & 30,71 &, $529 * *$ &,- 079 & 1 & & \\
\hline 4. Spor yaşı (yıl) & 7,02 & 3,54 &,$- 534 * *$ &, 104 &,$- 340 * *$ & 1 & \\
\hline 5. Mineral Mik. (kg) & 4,43 & ,66 &,- 027 &, $421 * *$ & , 168 &, 085 & 1 \\
\hline 6. Protein Mik. (kg) & 12,65 & 1,50 & ,109 & ,310* & ,008 & ,128 &, $272 *$ \\
\hline
\end{tabular}

Bu bulgulara göre, yapılan çoklu doğrusal regresyon analizler sonucunda sağ sol bacak kas miktarı ortalamaları, dinlenik kalp atımı, 1sınma sonrası kalp atımı ve anaerobik dayanıklılık sonrası kalp atımı değişkenleri çoklu eş doğrusallık sorunu yarattı̆̆ından (1-R2) regresyon denklemine alınmamış ve regresyon denklemi şu şekilde oluşturulmuştur; Y(anaerobik dayanıklılık $=[24,169($ Sabit $)+0,210($ VKİ $)+0,044($ Isınma kalp atımı $)+-0,363($ Spor Yapma Yaş1 $)+-0,841($ Mineral Mik) + 0,325(Protein Miktarı)].Değişkenlere ilişkin çoklu doğrusal regresyon sonuçları Tablo 4'de verilmiştir. 
Serin, E. (2019). Profesyonel, amatör ve sedanter futbol oynayanların fiziksel, fizyolojik ve motorik özelliklerinin değerlendirilmesi. Anaerobik dayanıklılıklarını etkileyen faktörlerin belirlenmesi CBÜ Beden Eğitimi ve Spor Bilimleri Dergisi, 14 (2), 344-355.

Tablo 4. Çoklu Doğrusal Regresyon Analiz Sonuçları

\begin{tabular}{lrrrrrrrr}
\hline Değişkenler & $\mathrm{B}$ & $\mathrm{SH}$ & Beta $(\beta)$ & $\mathrm{t}$ & $\mathrm{Sig}$ & Tolerans & VíF & D-W \\
\hline Sabit & 24,169 & 3,796 & - & 6,37 &, 000 & - & - & \\
VKİ (kg/m2 ) &, 210 &, 144 &, 16 & 1,46 &, 151 &, 761 & 1,314 & \\
Isınma.Kah. &, 044 &, 011 &, 43 & $3,98^{*}$ &, 000 &, 825 & 1,212 & 1,907 \\
(atım/dk) & & & & & & & \\
Spor yaşı (yıl) &,- 363 &, 094 &,- 41 & $-3,85^{*}$ &, 000 &, 855 & 1,170 & \\
Min.Mik. (kg) &,- 841 &, 543 &,- 18 & $-1,55$ &, 127 &, 752 & 1,329 & \\
Pro.Mik. (kg) &, 325 &, 221 &, 16 & 1,47 &, 147 &, 871 & 1,148 & \\
\hline
\end{tabular}

$\mathrm{R} 2=.48$; Düz. R2= .43; $\mathrm{F}=(5,54)=9,91 ; * \mathrm{p}<0.05$

Bağımlı değişken $($ Yordanan $)=$ Anaerobik Dayanıklılık

Bağımsız değişkenler (Yordayanlar) = BKI, ISIN.KAH, Spor Yaşı, Min. Mik.(Kg), Pro. Mik.(Kg).

Tablo 4 incelendiğinde, çoklu doğrusal regresyon analiz sonuçları anlamlıdır $[\mathrm{F}(5,54)=$ $9,91, \mathrm{p}<0,05]$. Düzeltilmiş R2 değeri. 43’tür. Bu sonuç, anaerobik dayanıklılı̆̆ $\% 43$ düzeyindeki varyans VKİ, ısınma sonrası kalp atımı, spor yapma yaşı, mineral miktarı ve protein miktarı değişkenleri tarafından açıklanabilmektedir. Ancak, tablodaki Beta katsayıları incelendiğinde; tüm bağımsız değişkenler regresyon modeline dâhil edildiğinde anaerobik dayanıklılığı açıklamada sadece 1 sınma sonrası kalp atımı $(\beta=, 43 ; \mathrm{t}=3,98, \mathrm{p}<0,05)$ ve spor yapma yaẃú $(\beta=$ $, 41 ; \mathrm{t}=-3,85, \mathrm{p}<0,05)$ değişskenlerinin anlamlı katkısı varken, diğer değişkenler olan VKİ $(\beta=, 16$; $\mathrm{t}=1,46, \mathrm{p}>0,05)$, mineral miktarı $(\beta=-, 18 ; \mathrm{t}=1,55, \mathrm{p}>0,05)$ ve protein miktarı $(\beta=, 16 ; \mathrm{t}=1.47$, p >0,05) değişkenlerinin modele anlamlı katkıları olduğu sonucuna varılmıştır.

\section{TARTIŞMA ve SONUÇ}

Araştırmaya katılan futbolcuların yaşları ortalamaları, 22,65 $\pm 3,68$ yıl, boyları ortalamaları $1,76 \pm 0,10 \mathrm{~cm}$, vücut ağırlığ $71,95 \pm 8,53 \mathrm{~kg}$, ve vücut kitle indeksleri ortalaması $22,96 \pm 2,46 \mathrm{~kg} / \mathrm{m} 2$ olarak tespit edilmiştir. Karakulak, Eyuboğlu ve Aslan (2018)'de yapmış oldukları çalışmalarında elde ettikleri demografik bilgi sonuçları çalışmamıza benzerlik teşkil etmektedir. Taşkın'ın (2009) futbolcular üzerine yapmış olduğu çalışmasında sporculardan elde ettiği fiziksel değiş̧enler ve dayanıklılık performans değerleri, çalışmamızda bulunan yaş, boy ve vücut ağırlığı değerleri be dayanımları ile benzerlik göstermektedir.

Futbolculardan elde edilen Vücut kitle indeksi (VKİ) değerleri; 22,96 $\pm 2,46 \mathrm{~kg} / \mathrm{m} 2$ olarak belirlenmiştir. Arslan ve Koç (2015) yapmış oldukları çalışmalarında elde ettikleri değerler 
Serin, E. (2019). Profesyonel, amatör ve sedanter futbol oynayanların fiziksel, fizyolojik ve motorik özelliklerinin değerlendirilmesi. Anaerobik dayanıklılıklarını etkileyen faktörlerin belirlenmesi $C B \ddot{U}$ Beden Eğitimi ve Spor Bilimleri Dergisi, $14(2), 344-355$.

çalışmamızdan elde edilen değerlere oldukça benzerlik göstermektedir. Yine VKİ açısından literatür araştırmaları göz önünde bulundurulduğunda, Doğan ve ark., (2016) yapmış olduğu çalışma ve Kumartaşlı ve ark., (2011) futbolculardan elde ettikleri VKİ değerleri, bu çalışmada elde edilen sonuçlar ile benzerlik göstermektedir. Bu durum futbol oynayanların benzer fiziksel özelliklerde olduğunu destekler nitelikte olabilir.

$\mathrm{Bu}$ çalışmaya katılan futbolculardan elde edilen değerler göz önünde tutulduğunda, anaerobik dayanıklılık performans ortalamaları 32,59 $\pm 3,14$ saniye, 1sınma sonrası kalp atım ortalamaları $130,70 \pm 30,70 \mathrm{ad} ı \mathrm{~m} / \mathrm{dk}$, spor yapma yaşları ortalamaları ise $71,95 \pm 8,53$ yıl olarak tespit edilmiştir. Serin ve Taşkın'ın (2016) yaptığı benzer bir çalışmada sporculardan elde etikleri fiziksel değişen değerler ortalaması çalışmamız ile benzerlik göstermektedir. Serin'nin (2018) yapmış olduğu çalışmasında, çalışmaya katılan sporculara ait fiziksel değişenler değerleri çalışmamıza yakınlık göstermektedir. Bu durumun futbolcuların yapmış olduğu antrenmanlar sonucu futbolun gereksinimlerine özgü fizyolojik yatkınlığı kazanmaları şeklinde açıklanabilir.

Araştırmaya katılan grupların VKİ, sağ ve sol bacak kas miktarı ortalamaları, mineral miktarı ve protein miktarı değişkenleri bakımından gruplar arasındaki sıra farkları anlamlı bulunmamıştır ( $>>0,05)$. Ancak dinlenik kalp atımı, sıra farklarına göre düşük değerden büyük değere doğru gruplar sıralandığında farkın anlamlı olduğu görülmüştür $(X 2=36,935, p<0,05)$. Hesaplanan sıra ortalama değerlerine bakıldığında; katılanların dinlenik kalp atımı değişkeni bakımından profesyonel olanlar $(815,41)$, sedanter olanlar $(50,21)$ ve amatörler $(29,89)$ biçiminde sıralanmaktadır. Kruskal Wallis H testi sonuçlarına göre ısınma sonrası kalp atımları değişkenine göre yine grupların sıra farkları incelendiğinde amatör ve sedanter gruplar arasındaki sıra farkı anlamlı bulunmuştur $(X 2=35,935, \mathrm{p}<0,05)$. Grupların sıra ortalama değerleri incelendiğinde amatörler $(19,58)$ ve sedanterler $(50,21)$ biçiminde sıralandı̆̆ dayanıklılık değişkeni bakımından incelendiğinde gruplar arasındaki sıra farkları anlamalı bulunmuştur $(\mathrm{X} 2=31,812, \mathrm{p}<0,05)$. Grupların sıra ortalama değerleri profesyonel $(15,14)$, amatör $(33,11)$ ve sedanterler $(45,68)$ biçiminde olduğu görülmektedir. Yine analiz sonuçlarına göre spor yapma yaşı bakımından grupların sıra farkları anlamalı bulunmuştur $(X 2=30,736, p<0,05)$. Grupların sıra ortalama değerleri incelendiğinde profesyoneller $(44,18)$, amatörler $(31,11)$ ve sedanterler $(14,05)$ olarak sıralandığı anlaşılmaktadır. Bunun yanı sıra anaerobik dayanıklılık 
Serin, E. (2019). Profesyonel, amatör ve sedanter futbol oynayanların fiziksel, fizyolojik ve motorik özelliklerinin değerlendirilmesi. Anaerobik dayanıklılıklarını etkileyen faktörlerin belirlenmesi CBÜ Beden Eğitimi ve Spor Bilimleri Dergisi, 14 (2), 344-355.

performansını; iyi bir ısınma ve spor yapma yaşının olumlu yönde etkilediğini, fakat VKi, mineral ve protein miktarının katkısı olmadığını tespit ettik.

Akın ve ark., (2004) yapmış oldukları çalışmalarında, izokinetik diz kaslarının konsantrik kuvveti ile ilgili bazı parametrelerde profesyonellerin, bazılarında ise amatörlerin daha yüksek değerlere sahip olduğunu, esneklikte amatörlerin daha yüksek değere sahip olduğunu, relatif bacak kuvveti açısından gruplar arasında anlamlı bir fark olmadığını belirtmişlerdir. Dikey sıçrama ve relatif bacak kuvvetinde ise istatistiksel olarak fark bulunamamıştır. Bu durumun şiddeti ve kapsamı yüksek antrenman drilleri gerçekleştirmelerinden kaynaklı olduğu düşünülebilir. Buğdaycı (2000) ve Emre (2000) ise, profesyonel ve amatör futbolcuları karşılaştırdıkları araştırmalarında, gruplar arasında, bacak kuvveti, relatif bacak kuvveti ve dikey sıçrama açısından Besler ve ark., (2010). ise esneklik, bacak kuvveti ve dikey sıçrama açısından anlamlı fark olmadığını bulmuşlardır.

Sonuç olarak; bu çalışmadan elde edilen veriler değerlendirildiğinde ve literatür bilgiler incelendiğinde, yapılan çalışmaların bazılarının çalışmamıza benzerlik gösterdiğini, bazılarının da farklılık gösterdiği tespit ettik. Bu çalışmadan elde edilen verilerin değerlendirilmesi sonucu; grupların genel değişenlerinin profesyonel, amatör ve sedanter şeklinde sıralandığını görmekteyiz. Bireylerin fiziksel özelliklerinin, çeviklik, sürat, çabukluk gibi motorik özellikleri etkilediği aynı zamanda anaerobik dayanıklılıklarını etkilediği bilinmektedir. Bu durumun sebebinin profesyonel sporcuların sezon öncesi ve sezon boyunca şiddeti ve kapsamı yoğun antrenman çalışmaları yapması aynı zamanda hayatlarını bu şekilde kazanmaları göz önünde bulundurulduğunda, gerek performans anlamında gerek fiziksel özellikleri bakımından üst düzey bileşenlere sahip olmaları gerektiği şeklinde düşünülebilir. Amatör sporcuların çok fazla maddi kazanç elde etme güdüsü olmadığından aynı zamanda spor yapma ihtiyaçlarının genel sağlık ve fizik durumlarını korumak yahut rekreasyon faaliyetine katılmak şeklinde gerçekleştiğinden ötürüdür ki profesyonellere oranla daha düşük değişen ve bileşenlere sahip oldukları düşünülmektedir. 
Serin, E. (2019). Profesyonel, amatör ve sedanter futbol oynayanların fiziksel, fizyolojik ve motorik özelliklerinin değerlendirilmesi. Anaerobik dayanıklılıklarını etkileyen faktörlerin belirlenmesi CBÜ Beden Eğitimi ve Spor Bilimleri Dergisi, 14 (2), 344-355.

\section{KAYNAKLAR}

Açıada, C. ve Ergen, E. (1990). Bilim ve Spor. Ankara: Büro-Tek Ofset Matbaacılık.

Akgün, N. (1994). Egzersiz, Fizyolojisi. İzmir: Ege Üniversitesi Basımevi.

Akın, S. Coşkun, Ö. Özberk, Z.N. Ertan, H. Korkusuz, F. (2004). Profesyonel ve amatör futbol oyuncularının fiziksel özellikler ve izokinetik diz kaslarının konsantrik kuvvetinin karşılaştırması. Klinik Araştırmaları Dergisi. 15(3):161-167.

Aslan, C.S. İnan, T. Akalan, C. (2010). Profesyonel bir futbol takımı ile beden eğitimi ve spor yüksekokulu öğrencilerinin bazı fiziksel ve fizyolojik özelliklerinin karşılaştırılması. E-Journal of New World Sciences Academy, 5(1): 47-58.

Aslan, C.S. Karakollukçu, M. (2010). Sezon öncesi hazırlık çalışmalarının bir süper lig takımının seçilmiş fiziksel ve fizyolojik özelliklerine etkileri. Spormetre Beden Ĕ̈itimi ve Spor Bilimleri Dergisi, 8(2): 51-56.

Aslan, C.S. Koç, H. (2015). Amatör futbolcuların seçilmiş fiziksel, fizyolojik ve motorik özelliklerinin mevkilerine göre karşılaştırılması. Celal Bayar Üniversitesi Beden Ĕ̈itimi Spor Bilimleri Dergisi, 10(1): 56-65.

Besler, M. Acet, M. Koç, H. Akkoyunlu, Y. (2010). Profesyonel ve amatör liglerde dereceye giren takımlardaki futbolcuların bazı fiziksel ve motorik özelliklerinin karşılaştırılması. Selçuk Üniversitesi Beden Eğitimi ve Spor Bilim Dergisi. 12(2):150- 156.

Buğdaycı, S. (2000). Profesyonel Futbolcularla amatör futbolcuların fiziksel parametrelerinin karşılaştırılması. Yüksek lisans tezi. Selçuk Üniversitesi ,Sağlık Bilimleri Enstitüsü. Konya.

Cerrah, A.O. Polat, C. Ertan, E. (2011). Süper amatör lig futbolcularının mevkilerine göre bazı fiziksel ve teknik parametrelerinin incelenmesi. Niğde Üniversitesi Beden Ĕ̆itimi ve Spor Bilimleri Dergisi. 5(1):1-6.

Doğan, G. Mendeş. B. Akcan, F. Tepe, A. (2016). Futbolculara Uygulanan sekiz haftalık core antrenmanın bazı fiziksel ve fizyolojik parametreler üzerine etkisi. Niğde Üniversitesi Beden Ĕ̈itimi ve Spor Bilimleri Dergisi, 10(1): 1-12.

Emre T. (2000). Niğde ilinde profesyonel ve amatör futbolcuların kuvvet parametrelerinin ölçülüp klyaslanması. Yüksek Lisans Tezi. Niğde Üniversitesi Sosyal Bilimler Enstitüsü. Niğde.

Günay, M. Erol, A.E. Savaş, S. "Futbolculardaki kuvvet, esneklik-çabukluk ve anaerobik gücün boy, vücut ağırlığı ve bazı antropometrik parametreler ile ilișkisi”, Hacettepe Üniversitesi Spor Bilimleri Dergisi, (5) 4 s:3-11. 1994.

Karakulak, İ. Eyuboğlu, E. Aslan, CS. (2018). Bir süper lig futbol takımının seçili fiziksel motorik ve teknik özelliklerinin incelenmesi. 16. Uluslararast Spor Bilimleri Kongresi Bildiri Kitabl; 258-259, Antalya.

Karatosun, H. (1991). Futbol Çocuk ve Gençlerin Ĕ̆itimi. Isparta: 2.Bask1, Altınoğlu Ofset.

Kumartaşlı, M. Suna, G. Çalışkan, İ.V. Işılda, K. Demir, M. (2011). Tenis ve futbol oyuncularının antropometrik özelliklerinin karşılaştırılması. Selçuk Üniversitesi Beden Eğitimi ve Spor Bilim Dergisi, 13(3): 372-377.

Özer, K. (2001). Ankara: Fiziksel Uygunluk. Nobel Yayınları.

Reilly, T. (1996). Science and Soccer. London: Ed. E \& FN Spon. Chapman\&Hall, 25- 64.

Serin, E. (2017). Relationshıp between the hip anatomy and sportıng performance. European Journal of Physical Education and Sport Science, 3(10):243-260.

Serin, E. (2018). "Effect of different stretchihg protocol on vertical jump performance." Sportif Bakış: Spor ve Ĕgitim Bilimleri Dergisi 5(1), 1-8.

Serin, E. Taşkın, H. (2016). Anaerobik dayanıklılık ile dikey sıçrama arasındaki ilişki. Spor ve Performans Araştırmaları Dergisi 7(1), 37-43.

Stolen, T. Chamarı, K. Castagna, C. Wisloff, U. (2005). Physiology of soccer. Sports Medicine. 35(6):501-536.

Şahin, H.M. (2006). Beden Ĕ̆itimi ve Spor Sözlüğü. İstanbul: Morpa Yayınları. 
Serin, E. (2019). Profesyonel, amatör ve sedanter futbol oynayanların fiziksel, fizyolojik ve motorik özelliklerinin değerlendirilmesi. Anaerobik dayanıklılıklarını etkileyen faktörlerin belirlenmesi CBÜ Beden Eğitimi ve Spor Bilimleri Dergisi, 14 (2), 344-355.

Taşkın, H. (2006). Profesyonel futbolcularda bazı fiziksel parametrelerin ve 30 metre sprint yeteneğinin mevkilere göre incelenmesi. Spormetre Beden Eğitimi ve Spor Bilimleri Dergisi.6(2):49-54.

Taşkın, H. (2009). Effect of circuittraining on thesprint-agility and snaerobic endurance. Journal of Strengeth and Conditional Assontion 23(6): 1806-1809. 